\title{
Death and Renewal in The Velveteen Rabbit: A Sociological Reading
}

\author{
Allan Kellehear, Ph.D. \\ La Trobe University
}

ABSTRACT: This article provides a sociological interpretation of The Velveteen Rabbit (Williams, 1922) critical of recent materialist and psychoanalytic readings. I argue that this children's story exemplifies the use of a nonmaterialist idea of death to suggest other themes about love and life, and discuss implications for near-death research.

Stories about personal survival over death attract interesting reactions in academic circles. But despite the widespread curiosity that those tales elicit, the predictability of the explanation often generated must impress even the most casual observer. From a diversity of disciplinary sources, from anthropology to semiotics to psychiatry, the epistemological assumptions that drive many of those explanations have a remarkable sameness to them. To cite a representative view, Maurice Bloch and Jonathan Parry (1982) argued that the themes of rebirth and tales of the afterlife in the context of death "deny the finality of death."

That materialist claim concerning the "finality" of death is assumed to be, and is so often presented as, a culturally neutral one. Consequently, those who resist the claim or who choose to believe otherwise are viewed as "religionists" of one persuasion or another or, alternatively, as troubled psyches. If religion or ignorance is not the explanation for this deviance, then a theory of unconscious defense mechanism such as denial or wish fulfillment can provide another explanation (Lorimer, 1990). The effect of this style of academic discourse is the lasting impression of an academy unable to free itself

Allan Kellehear, Ph.D., is Senior Lecturer in Sociology at La Trobe University. Reprint requests should be addressed to Dr. Kellehear at the Department of Sociology, La Trobe University, Bundoora 3083, Australia. 
from its nineteenth-century reaction to religious ideas. Nowhere is this psychoanalyzing tendency more clearly evident today than in social and literary explanations of death and loss in children's stories, as for example in the writings of Bruno Bettelheim (1978) and Margaret and Michael Rustin (1987).

My goal in this essay is to provide an alternative reading to a children's story that celebrates images of death and incorporate ideas of renewal. I have chosen The Velveteen Rabbit (Williams, 1922) as my case example for two reasons. First, this story contains a famous portrayal of these themes of death and renewal, and interestingly, the actual images described are strikingly similar to the near-death experience. Second, the academic story of The Velveteen Rabbit, a recent development that includes attempts by some critics to substitute psychoanalysis for narrative analysis, raises certain implications for neardeath studies that are worth closer scrutiny. The purpose behind this goal is to demonstrate that ideas about death which encompass personal survival are not better understood when analyzed in terms of psychoanalytic defense theory. Indeed, the habitual application of this framework to all manner of death imagery becomes a reductionist practice that restricts rather than enhances our understanding of different cultural meanings of death.

The Velveteen Rabbit has attracted its share of psychoanalysis for its refusal to acknowledge "the finality of death": the rabbit's death scene fails to result in the obliteration of the rabbit's life. The fact that the rabbit's death does not conform to the materialist view of death led critic Steven Daniels (1990) to complain the The Velveteen Rabbits image of death is "phoney," and prompted him to channel the analysis into a study of the psychodynamics of defense, motive, and symbol. I argue that this approach is both unnecessary and decontextualizing.

The theme of renewal and survival in the face of death is a necessary narrative device for the support it gives to more important themes, at least for young readers. These broader themes speak to the mutual interdependence of relationships and the triumph of love in the face of change and transformation in life, particularly in the context of growing up.

In support of this argument I organize the paper along the following lines. First I will provide a brief summary of the story of The Velveteen Rabbit. This will be followed by a discussion of the recent critical concern over its images of death and renewal. I will then provide an alternative reading of the images and will argue that this interpretation is consistent and more in keeping with the spirit and values of the narra- 
tive as a whole. The final part of the essay will sketch some implications of this exercise for other interest areas within near-death studies.

\section{The Story of The Velveteen Rabbit}

The Velveteen Rabbit appeared in 1922 under the pen of Margery Williams. Accompanied by the charming lithographs of William Nicholson, The Velveteen Rabbit quickly assumed the status of a children's story classic (Stott, 1984). In 1971 it was the winner of the Lewis Carroll Shelf Award and in the 1980s when the copyright ran out in the United States, several new editions with different illustrations appeared (Weales, 1983). Its popularity was so great at one time that one reviewer described it as having "become a cult in the United States" (Fisher, 1971), noting that parts of the book were regularly quoted in sermons.

In this simple story written for children between the ages of 5 to 9 , the Velveteen Rabbit begins his life in the story as a gift inside a boy's Christmas stocking. After the initial excitement of receiving the rabbit, the Boy moves his interest to other toys found among the chaos of the Christmas paraphernalia. For a long time after that first day the Rabbit lives forgotten, with other neglected toys, in either the toy cupboard or on the nursery floor.

He is befriended by an old Skin Horse. Deep into the long, silent nights the Skin Horse and the Velveteen Rabbit hold long conversations. The most critical discussion, from the story's point of view, is the following oft quoted exchange:

"What is REAL?" asked the Rabbit one day, when they were lying side by side near the nursery fender, before Nana came to tidy the room. "Does it mean having things that buzz inside you and a stick out handle?"

"Real isn't how you are made," said the Skin Horse. "It's a thing that happens to you. When a child loves you for a long, long time, not just to play with, but REALLY loves you, then you become Real."

"Does it hurt?" asked the Rabbit.

"Sometimes," said the Skin Horse, for he was always truthful. "When you are Real you don't mind being hurt." 
"Does it happen all at once, like being wound up," he asked, "or bit by bit?"

"It doesn't happen all at once," said the Skin Horse.

"You become. It takes a long time. That's why it doesn't often happen to people who break easily, or have sharp edges, or who have to be carefully kept. Generally by the time you are Real, most of your hair has been loved off, and your eyes drop out and you get loose in the joints and very shabby. But these things don't matter at all, because once you are Real you can't be ugly, except to people who don't understand." (Williams, 1922, pp. 16-17)

Not long after this exchange, the Boy takes the Velveteen Rabbit to bed with him after being unable to locate his regular toy companion. From then onwards, the story follows the growing relationship and mutual attachment of the Boy and his Rabbit through the various seasons of their friendship. Throughout this narrative the story is told from the Rabbit's point of view. On three further occasions the question of what is real emerges in one way or another in the story.

On the first of these occasions the Boy is unable to retire to bed without the Rabbit, which is accidentally left on the lawn outside. On returning the Rabbit to the Boy, Nana expresses her incredulity at "all that fuss" over a toy, to which the Boy retorts, "You mustn't say that. He isn't a toy. He's REAL!" (p. 24).

On the second occasion, the Rabbit is propped up in the garden somewhere and is visited by two wild rabbits. They are at first curious, and quietly and cautiously move closer to the Velveteen Rabbit to inspect him. Then follows a series of exchanges between the wild rabbits and the Velveteen Rabbit. The conversation ends when one of the wild rabbits comments, "He doesn't smell right! ... He isn't a rabbit at all! He isn't real!" (p. 30).

In the final part of the story, the Boy is stricken with scarlet fever for many weeks and is bedridden with the Rabbit by his side. When he is finally well enough to leave his bed, the doctor and Nana conspire to dispose of the Rabbit because now this toy was "a mass of scarlet fever germs!" (p. 34). The Velveteen Rabbit is replaced with a new rabbit toy but the story of the Velveteen Rabbit does not end here. The Velveteen Rabbit is stuffed into a sack by the garden shed in preparation to be burned. That night, alone and in grief, the Rabbit reviews all the good times he had with the Boy. At this point the final question concerning the nature of real is asked: 
"Of what use was it to be loved and lose one's beauty and become Real if it all ended like this? And a tear, a real tear, trickled down his shabby velvet nose and fell to the ground" (p. 37).

From the spot where the tear fell grows a flower, and inside that flower appears a being of gold and pearl perfection, the nursery Magic Fairy. This Fairy takes care of all the playthings that have been loved but are no longer needed by children. The Velveteen Rabbit is transformed into a wild rabbit and is taken to Rabbitland to join all the other wild rabbits "to live... for ever and ever" (p. 40).

\section{Critics' Responses to the Book}

The above ending has been the focus of some very disappointed criticism, mainly from Faith McNulty (1982) and Gerald Weales (1983). McNulty (1982) described the message conveyed by this ending as "sad," "sleazy," and "false as a three dollar bill." McNulty criticized the story for not providing ideas about positive ways of meeting the "tragedy of lost love and betrayal (without) letting the heart break" (p. 180).

Continuing in this vein Weales (1983) wondered why the Rabbit's magical reward did not extend to his old friend the Skin Horse, a point also noted by Daniels (1990) and described as an "inconsistency." Weales also regarded the ending as a transformation brought about by self-pity rather than the power of love. Daniels (1990), pondering these complaints, offered psychoanalysis, "in particular Melanie Klein's theories," as a way of "confronting the question at the heart of the story" (pp. 17-18). The question Daniels argued to be at the heart of the story is ironically the last one described at the end of the story: "Of what use was it to be loved ... and become Real if it all ended like this?" By focusing on this as the central question of The Velveteen Rabbit, Daniels was able to argue that the story is about the "ambivalence toward separation," a burden resolved only through "idealization." Idealization in the form of the Fairy is viewed as a defense mechanism, one way of resolving "the persecutory anxiety involved in feeling oneself abandoned by the allimportant person"' (p. 27). The story of The Velveteen Rabbit was argued by Daniels to be an analogy for the inner life of infants or children. Furthermore, he argued that the Kleinian interpretation is a "standard against which the question it poses can be best understood" (p. 27).

There are several problems with these views. To begin with Daniels's final comment, there are no definitive standards in the semiotic arts 
save those agreed to by consenting like-minded readers. As Ann Game $(1991$, p. 5) argued, textual analysis should not be understood as simply "representation but as itself a writing or discursive practice." In other words, interpretations can be seen as another way of reading or telling the story and these are subject to the particular cultural characteristics of audience and readership.

The Kleinian interpretation is rather esoteric as a reading and therefore may not resonate with audiences outside psychoanalytic circles. This does not of course invalidate the interpretation, but it does suggest that the matter of which frameworks are best able to understand the central question of the story might still be yet to be settled. There are two further reasons for suggesting this.

First, the psychoanalytic reading does not identify or explore simpler social and moral themes, even if only to connect these themes to the defensive ones of a Kleinian interpretation. And yet these simpler social themes may be more accessible to the emotional sensibilities of young readers. In this way these themes may be more influential in the receiving and shaping of the inner thoughts and feelings of young readers.

Second, the question that Daniels argued to be at the "heart" of the story is, I believe, not the central one at all. On the contrary, the question asked by the Rabbit during that dark night in a sack should be seen in a support role to the story's overall theme. If seen in that context, the story is also not about the "ambivalence of separation." These points tend to erode the credibility and therefore the persuasive power of a psychoanalytic interpretation of death and renewal in the story of The Velveteen Rabbit. In support of these observations I will first discuss what I believe to be the central question of the story. I will then move on to identify how the Rabbit's death scene continues and extends the main theme and, in the context of that discussion, will address the other concerns of McNulty (1982) and Weales (1983).

\section{A Sociological Reading}

\section{The Central Question of the Story}

The central question of The Velveteen Rabbit, around which both the plot and the recurring symbols revolve, is "What is real?" This question causes the only prolonged verbal exchange in the book, between the Velveteen Rabbit and the old Skin Horse. Furthermore, this question is further developed in exchanges between Nana and the Boy, the wild 
rabbits and the Velveteen Rabbit, and, of course, in the scene toward the end between the Rabbit and the nursery Magic Fairy.

In the first major treatment of this question, the Skin Horse is careful to point out to the Rabbit that "real" has nothing to do with having "proper insides." It is not therefore an issue of biological or mechanical authenticity. It is not about composition, make-up, or even pedigree in any absolute and reductionist sense. Rather real is "What happens to you," in other words, how you are changed by interaction with others. It is the perceived enjoyment and exchange of affections, the wear and tear, literally, of social interaction that sets in place the process of change. Real is actually a social and physical process of change that can transform a toy into a friend, from simple object to a prized play relation. And as that friendship develops the material wear on those toys becomes the measure of a toy's social value.

This idea of real as the social construction of identity through friendship is further developed in the exchange between Nana and the Boy. When the Boy asks Nana to refrain from referring to the Rabbit as simply a toy and vehemently asserts its real-ness, he is reaffirming this social relationship between two social identities, himself and the Rabbit. Real means "loved" or "precious." It means "real to me and for my purposes." The Boy's relationship with the Rabbit fulfills all the vital functions of friendship and is therefore for all intents and purposes real, that is, socially real.

The Boy's reality then, is a social reality defined by attachment. This is a bond cemented and maintained by the shared experiences of companionship, a companionship believed to be reciprocal. Besides this reality, the material reality of the world is not reality at all, at least not for the boy.

The Gardens of Play are stages, and the wild rabbits are part of that stage as props and scene pieces, but they do not constitute the real action, which follows the Boy's ideas in a social world that the Boy creates. Part of the exchange with the wild rabbits about what is real is revealing here:

"Why don't you get up and play with us?" one of them asked.

"I don't feel like it," said the Rabbit, for he didn't want to explain that he had no clockwork.

"Ho!" said the furry rabbit. "It's as easy as anything." And he gave a big hop sideways and stood on his hind legs. 
"I don't believe you can!" he said.

"I can!" said the little Rabbit, "I can jump higher than anything!" He meant when the Boy threw him, but of course he didn't want to say so. (pp. 28-29)

These wild rabbits appear to be a major contrast to the social reality of the Velveteen Rabbit until one realizes that, their biological appearance notwithstanding, these rabbits talk. The poetic license taken in this respect further highlights that the world of the Boy and his Rabbit is a socially constructed world in every major respect. This is not an ontologically inferior world, because like our own empirical world, the material is necessary - but not the authoritative blocks with which we build our meanings. Furthermore, the subtle emphasis on the social nature of things becomes an increasingly important perspective, which is developed to complement and support the story's unfolding theme.

The final exchange concerning the nature of what is real is between the Fairy and the Rabbit. The Velveteen Rabbit was real to the Boy but now would be made "real to everyone." But did the Fairy mean real as the biologically real wild rabbits, or real as in the Boy's and Skin Horse's meaning? Initially the evidence appears conflicting.

On the one hand, Rabbitland seems to be the place where all the wild rabbits live and play. The actual final scene describes the Velveteen Rabbit, now a wild rabbit, visiting the Boy from a distance. They exchange looks in this final scene and the Boy, just for a moment, is reminded of his old Velveteen Rabbit from the markings on the real rabbit he sees.

On the other hand, the Velveteen Rabbit is meant "to live ... for ever and ever" with them. If they are biologically real wild rabbits, "for ever and ever" amounts to about eighteen months (Lockley, 1965). This hardly amounts to immortality. This suggests that "Rabbitland" has similar features to an actual biological rabbit culture, but in fact departing from it in important ways. Similar to the Spiritualist's Summerland, then, here is a transformation of some aspects of shape and function but preservation, or at least remnant persistence, of others.

Once again, then, the physical shape and form of things play only a minor role in the social construction of their meaning and value for all the participants. Far more important are the processes of identity construction and transformation derived from love than the substance of any single event, such as hurt, death, discomfort, or inherited characteristic, such as polished eyes or shiny fur. The Fairy's attitude to what 
is real, then, seems consistent with those asserted by the Boy and the Skin Horse earlier in the story, and also in the spirit of the images of biologically real rabbits that talk. The Velveteen Rabbit becomes "real to everyone" only insofar as the wild rabbits themselves are understood to be real in Williams's sociable, chatty, but anthropomorphic portrayal. More than this, though, the Velveteen Rabbit will also become socially real to the readers and listeners of the story. When boys and girls encounter biologically real rabbits in the future, each may ask: whose rabbit do I see before me now? Which boy or girl has made this rabbit real? The relationship between animals and children is no longer viewed merely in biological terms but more importantly in social ones. And so it is in the pursuit of the question "What is real?" in each of these major scenes that the main narrative energies are absorbed and dedicated.

The death scene is the final dramatic and supporting contribution to this question of what is real. This scene amounts to a tale of personal survival and rebirth for the Rabbit. Death in this story is not presented as the final triumph of loss and despair over attachment and love, but rather the final evidence that loss and despair are unable to surmount what was not theirs to surmount in the first place. In this respect the narrative reality of The Velveteen Rabbit is not the triumph of a materialist theory of existence, which exemplifies the inevitable competitive edge death has over all life (Freud, 1961). And perhaps it is this departure from conventional psychoanalytic wisdom that attracts so much suspicion and disappointment from those so inclined.

Instead, Williams's message is for children not to be seduced by the confusing and irregular appearance of love and loss in life. They are encouraged to realize that love and loss are constant riding companions in the rough and tumble of life's unpredictable splendor. It is not loss that is triumphant but rather the love that can emerge from, and triumph over, the complex and unpredictable nature of life's changing fortunes.

For example, at the beginning of the story we witness the attachment between the Boy and the Rabbit on Christmas morning. Loss follows some hours after as the Boy's interests move on to other toys. This absence lasts a long time and leads to the friendship between the Rabbit and the old Skin Horse. This friendship, in turn, ends when the next period of attachment begins with the Boy. The initiative gained by this attachment is the centerpiece of the story itself and is overtaken by loss only after the scarlet fever incident. At this point, the death or separation scene toward the end of the story should now, in this con- 
text, be read not as "idealization" or "denial" but as a narrative device. But this device does not support some simple biological conception of life that, as I have argued above, is never shared by the main players anyway. Rather a concept is developed of an existence where change and transformation are paramount and integral to both the story and, indeed, life itself.

The story in general then impels its young readers and listeners to treat all their toys as socially real and to care for them. The story's images suggest that toys are dependent and vulnerable creatures-like children themselves. The toys eventually change to become almost unrecognizable from their original selves-again, like growing children themselves. The exhortation is to care for each other, to show kindness and affection, until that time when everyone becomes real. Children become socially real when they grow up to be adults and toy rabbits become real when they lose their shape and are no longer required as playthings.

The comparatively complex idea that becomes essential to convey to young readers at this point is the intrinsic and inevitable involvement of everyone in this process. Love, and the care and kindness that are its hallmarks, do not guard against loss and death. Love paradoxically creates these other experiences. Without attachment it is loss that cannot exist, and without love it is death that has no dominion. This is why becoming "real" does not happen very often "to people who break easy, or who have sharp edges, and who have to be carefully kept."

\section{The Continuing Theme}

To convey this theme one final and impressive time, the Velveteen Rabbit undergoes a death that has remarkable similarities to our understanding of the near-death experience (NDE). Death begins with the final separation from the Boy. The Rabbit is stuffed into a dark sack, a symbol coincidentally used by Leo Tolstoy to convey the onset of death (Tolstoy, 1960). Re-emerging from that sack, the Velveteen Rabbit reviews his life and all his major social events and relationships. He then encounters a special being in the form of a Fairy and is taken to another place and another life. Here the world is both different and similar to his former world but a place where immortality reigns. Daniels (1990) and Weales (1983) before him implied that this is an ending not shared by the Skin Horse. However, there is no evidence to be found anywhere in the story that the Skin Horse was at the end of 
its use. After all, the Skin Horse lived in the nursery with other toys, perhaps forgotten but not discarded. The Velveteen Rabbit, on the other hand, faced death by incineration the next morning. This eventuality was carefully created and described for the Rabbit's unique role in the story as the Boy's favorite toy.

The death narrative in the final part of the story continues the theme of the triumph of love in the face of the unpredictable nature of events. In that context, Williams's death scene is a device that supports her philosophy of life. (This is not a surprise given our knowledge of her family's tendency to move so frequently during her childhood [Ferris, 1952].) But Williams had not made the death scene thematically central. As a plot climax it has always played a support role to the social and poetic theme developed throughout the rest of the story. How does this death scene, highlighting the problem of loss, actually privilege the theme of love as developed by the story so far?

First, the feelings of loss experienced by the Rabbit are actually a consequence of his love for the Boy, a love that pines and despairs at the prospect of permanent separation. The appearance of the Fairy, in its turn, is actually a consequence of the Boy's love since, according to the Fairy's own account, she only takes "care of all the playthings that [children] have loved" (p. 38). Love, therefore, and particularly the fate of love when confronted by loss, is the concern that is privileged in the interaction between the Fairy and the Rabbit.

Second, both the Fairy and Rabbitland as images of death and renewal deliver an important message that celebrates the general theme of the book: that love can triumph over loss. Love does not diminish with change but can continue in transformed ways in spite of it. This is because both children and their toys live on as memories and dreams, the past a living social presence and influence on the present.

In this context Rabbitland demonstrates the importance of the social rather than material nature of love one more time. It continues the theme that love's heart does not miss a beat even if "most of your hair has been loved off, and your eyes drop out and you get loose in your joints and very shabby" (p. 17). In other words, neither age nor death, as material appearances that can deceive, should be permitted to define the limits of emotional and social attachment.

Finally, the portrayal of Rabbitland as an empirically real place has parallels with retelling NDE accounts. Carol Zaleski (1987) argued that such portrayals help listeners and readers connect future possibilities with present circumstances and actions in one's imagination. This facilitates the shaping of present priorities and attitudes, and this 
is exactly the desire of many storytellers, including Williams. The existence of Rabbitland, then, is a narrative device that helps young readers understand through their imagination how love might cope in the context of loss.

The message that love is a social relationship where material conditions are not necessarily determining factors is a message first told by the Skin Horse in the nursery. And it is this message, in this final form, that makes the death scene after all a convincing narrative about the power of love and not, as Daniels (1990) argued, about separation.

This message encourages the development of a more sophisticated idea about relationships that can facilitate a personal ability to transcend loss. This is because, as Williams reminds us, love enables our attachments to stay on with us as living influences on our thoughts, feelings, and actions. This is no denial of death but rather a moving beyond it, a refusal to be defined and immobilized by it. Objects and experiences are personalized through the processes of attachment, and this in turn creates the intellectual and emotional reality of social life. The importance of this principle is echoed by Williams herself when she remarks that "It is through imagination that a child makes his most significant contacts with the world around him, that he learns tolerance, pity, understanding and the Love of all created beings" (quoted in Stott, 1984, p. 34).

It is true that the idea of loss has a presence, but it is neither the final nor the dominating theme of the story. This is because, as I have argued, its narrative context is the transforming power of love and its survival and even triumph in the face of personal and social change. McNulty (1982) was therefore incorrect when she complained that "the book gives no hint that there is any way to meet the tragedy of lost love and betrayal." To put the matter rather simply, no love was lost in the story of The Velveteen Rabbit. Furthermore, there was no betrayal either, certainly not from that "all important person," the Boy.

Although the Rabbit was discarded by the Boy's guardians and not, it should be well noted, by the Boy himself, the love between them continues on in both their subsequent lives and memories. Therefore the story's theme is not about the "ambivalence of separation" (Daniels, 1990) but rather the robust ability of love to transcend separation, even in death.

Nor is the final transformation of the rabbit brought about by "selfpity," as Weales asserted. Rather the author shows, and shows consistently, that the love between the Boy and his Rabbit does not simply 
die with the material presence of one of them. This is not a case of outof-sight and out-of-mind. Rabbitland is a "life after death" for the Rabbit, and this encourages young readers to entertain the social presence and influence of a relationship long after its material existence has come to an end.

Acknowledging the ongoing fertile influence of past relationships on the life of present ones is not an easy personal exercise for most adults, let alone children. The near-death imagery of the death scene facilitates an empathy for those social but invisible influences in all our lives. Far from being motivated by self-pity, the images of death and renewal are an inspired set of images drawn for a specific pedagogic purpose. This purpose is to provide effective and imaginative support for the story's final message, that real love continues even when the beloved is taken away.

And so continuing toward that end Williams wrote, using the seasonal language of the grieving heart:

Autumn passed and Winter, and in the Spring, when the days grew warm and sunny, the Boy went out to play in the wood behind the house. And while he was playing, two rabbits crept out from the bracken and peeped at him. One of them was brown all over, but the other had strange markings under his fur, as though long ago he had been spotted, and the spots still showed through. And about his little soft nose and his round black eyes there was something familiar, so that the Boy thought to himself:

"Why, he looks just like my old Bunny that was lost when I had scarlet fever!"

But he never knew that it really was his own Bunny come back to look at the child who had first helped him to be Real. (p.44)

\section{Implications for Near-Death Studies}

Examining images of death and near-death in children's literature has several implications that differ somewhat from similar exercises with adult fiction (see for example Flynn, 1984; Straight, 1984; WrenLewis, 1986).

First, many social and literary commentators on children's literature, as we have seen in the present case study, are concerned when images of death turn into tales of rebirth. Drawing on materialist ideas 
about death, and having tolerance for little else, these reviewers look to a psychoanalytic theory for an explanation. But that reaction and writing itself, through its own failure to grasp a plurality of ideas about death, overlooks the opportunity to explore cultural meanings of death different from their own. This psychoanalytic response is ethnocentric and renders problematic any concept of death associated with ideas of survival and rebirth. On these different notions of death are conferred a deviant status, a status which is at once both social and psychological.

That process, I believe, sells short the importance of understanding what death means to different people in different times and places with different social experiences of it. A sociological reading of The Velveteen Rabbit reveals the value of providing alternative models to psychoanalytic ones that portray death as annihilating and final. Unlike Freud's medical view of death as winner-takes-all (Freud, 1961), symbolic representations or social experiences of death are always context dependent. This is because sociological readings can assume that meaningful understandings of death derive from their logical relationship to other meanings that emerge from the context of a society or story. Images of death in The Velveteen Rabbit should be understood in terms of their narrative context. Concepts of death in psychoanalytic discourse should be seen in their historical and political context. And as Kenneth Ring (1991) has recently argued, personal NDEs should be read in their biographical context in much the same way that Zaleski (1987) viewed the public discourse about NDEs in the context of religious history. In that epistemology, no meaning of death need foreclose on another, whatever scientific rhetoric is used to justify and rationalize such a monopoly.

Because tales of rebirth in the face of death are commonly subject to the analytical dominance of materialist and psychoanalytic paradigms, at least in the social sciences, it is an important, critical task to provide alternative readings. This is because as Jean-Francois Lyotard (1984, p. 81) argued, the social and intellectual value of such rewriting and retelling helps "invent allusions to the conceivable which cannot be presented." And that exercise in turn opens up intellectual spaces where we can entertain and examine, with a range of methodological tools, the plurality of ideas about death that is part of our diverse human inheritance.

Second, Melvin Morse (1990) has recently demonstrated how childhood NDEs are strikingly similar to adult versions. He suggests that, 
since children are not fully socialized creatures, this may mean that cultural conditioning plays a minimal or no role in the NDE. Aside from the methodological problems of retrospective recall in many of these cases, the conclusion is perhaps premature for another reason. Children do not experience socialization suddenly, despite the desperate wishes of their parents. Socialization is incremental and gradual, dependent as it is on processes of physical and social development. The similarity of childhood NDEs to adult versions does not suggest that cultural conditioning is unimportant. Rather this finding could just as readily be interpreted as evidence that such conditioning penetrates rather early.

We can see that The Velveteen Rabbit, a story for children between the ages of 5 and 9, contains many of the classic images of the NDE. This story however, is not unique in these respects. In the Wizard of $\mathrm{Oz}$ (Baum, 1987), for example, Dorothy is transported inside the tunnel of a tornado to another place where she meets the "good witch of the east." In Lewis Carroll's (1965) Alice in Wonderland, Alice begins her adventure by a long fall down a dark rabbit hole. Children's literature is replete with tunnels, extraordinary beings, life reviews, flying experiences, and tales of reunion (Greene, 1992).

At least in the literate circles of industrialized nations, children have a wealth of imagery to draw upon to help them make sense of everyday and out-of-the-ordinary social experiences. These stories like those of The Velveteen Rabbit have a long history and they are read by or to children of very early ages. I do not argue in any reductionist way that childhood NDEs then are merely a product of these fantasies. But I do draw attention to the fact that children's stories can provide one source of cultural imagery (and there may be others) that might assist children in making sense of the NDEs.

Without some cultural materials it is doubtful that anyone, children or adults, would be able to communicate even minimally, let alone make personal sense of, foreign experiences such as the NDE. Individuals of any age are not culturally neutral beings. Therefore the descriptive narratives of NDEs should be understood in terms of the language of that communication, a point already discussed at some length by Zaleski (1987).

In that same work Zaleski $(1987$, p. 191) argued that "When one judges a symbol, one cannot say whether it is true or false, but only whether it is vital or weak" and this depends on "their capacity to evoke a sense of relationship." Few of the millions of readers who have 
read or heard the story of The Velveteen Rabbit since its appearance in 1922 accept the literal meaning of Rabbitland. But even fewer would argue against the social message of the story. Those of us who do not believe that love can triumph over loss wish nevertheless that it could. And that very desire to look again at the universal mystery of love and death continues to breathe new life into the story of The Velveteen Rabbit and to ensure that our relationship to tales of rebirth, of transcendence of death, remain vital and relevant.

\section{References}

Baum, L. F. (1987). The Wizard of $\mathrm{Oz}$. New York: NY: Ballantine.

Bettelheim, B. (1978). The uses of enchantment: The meaning and importance of fairy tales. New York, NY: Knopf.

Bloch, M., and Parry, J. (Eds.) (1982). Death and the regeneration of life. New York, NY: Cambridge University Press.

Carroll, L. (1965). Alice's adventures in Wonderland. New York, NY: Airmont.

Daniels, S. V. (1960). The Velveteen Rabbit: A Kleinian perspective. Children's Literature: An International Journal, 18, 17-30.

Ferris, H. (1952). Writing books for boys and girls New York, NY: Doubleday. Fisher, M. (1971). Review of The Velveteen Rabbit Growing Point, 9(7), 1657.

Flynn, C. P. (1984). Death and the primacy of love in works of Dickens, Hugo, and Wilder. Anabiosis: The Journal of Near-Death Studies, 4, 125-141.

Freud, S. (1961). Beyond the pleasure principle London, England: Hogarth.

Game, A. (1991). Undoing the social. Toward a deconstructive sociology. Toronto, Ontario: University of Toronto Press.

Greene, F. G. (1992). Motifs of passage into worlds imaginary and fantastic. Journal of Near-Death Studies, 10, 205-231.

Lockley, R. M. (1976). The private life of the rabbit: An account of the life history and social behaviour of the wild rabbit London, England: Andre Deutsch.

Lorimer, D. (1990). Whole in one: The near-death experience and the ethic of interconnectedness. London, England: Arkana.

Lyotard, J.-F. (1984). The post-modern condition: A report on knowledge. Minneapolis, MN: University of Minnesota Press.

McNulty, F. (1992, December 6). Children's books for Christmas. New Yorker, pp. 176-182.

Morse, M., and Perry, P. (1990). Closer to the light: Learning from the near-death experiences of children. New York, NY: Villard.

Ring, K. (1991). Amazing grace: The near-death experience as a compensatory gift. Journal of Near-Death Studies, 10, 11-39.

Rustin, M., and Rustin, M. (1987). Narratives of love and loss: Studies in modern children's fiction. London, England: Verso.

Stott, J. C. (1984). Children's literature from A to Z: A guide for parents and teachers. New York, NY: McGraw-Hill.

Straight, S. (1984). A wave among waves: Katherine Anne Porter's near-death experience. Anabiosis: The Journal of Near-Death Studies, 4, 107-123.

Tolstoy, L. (1960). The death of Ivan Ilyich and other stories New York, NY: New American Library. 
Weales, G. (1983, April 3). Children's books. New York Times Book Review, p. 13.

Williams, M. (1922). The Velveteen Rabbit, or how toys become real. New York, NY: Doubleday.

Wren-Lewis, J. (1986). Joy without cause: An anticipation of modern "neardeath experiences." Research in G. K. Chesterton's novel The ball and the cross The Chesterton Review, 12, 49-61.

Zaleski, C. (1987). Otherworld journeys: Accounts of near-death experience in medieval and modern times. New York, NY: Oxford University Press. 